\title{
Tatalaksana ulkus yang disebabkan oleh pecahnya abses peritonsilar Management of ulcer due to rupture of peritonsillar abcess
}

\author{
${ }^{1}$ Astrid Palmasari, ${ }^{2}$ Priyo Hadi \\ Departemen Oral Medicine \\ ${ }^{1}$ Fakultas Kedokteran Gigi, Universitas Hang Tuah \\ ${ }^{2}$ Fakultas Kedokteran Gigi, Universitas Airlangga \\ Surabaya, Indonesia
}

\begin{abstract}
Peritonsillar abcess is a infection of head and neck commonly seen. This infection is caused by infection organisme such as Streptococcus pyogenes (Group A Beta-Hemolitik streptococcus), Staphylococcus aureus, Haemophilus influenzae, Fusobacterium, Prevotella, Porphyromonas, and Peptostreptococcus spp. by the spreading of anaerob organism to one of loose aerolar space around pharynx and cause the abcess and penentrate to the tonsillar capsule but which is still in pharynx constrictor muscles boundary. This paper reports a male of 36 years old patient with chief complaint of ulcer on the hard palate accompanied with tonsillar swelling that made difficulty in swallowing. The diagnosis was ulceration due to peritonsillar abcess rupture. Amoxycyllin antibiotic, and benzydamine HCl gargle was precribed to cure the ulcers.
\end{abstract}

Key words: peritonsillar abcess, head and neck infection, benzydamine $\mathrm{HCl}$

\begin{abstract}
ABSTRAK
Abses peritonsilar adalah infeksi pada kepala leher yang sering kali terjadi. Abses peritonsilar terbentuk oleh karena penyebaran bakteri anaerob yaitu Streptococcus pyogenes (Group A Beta-Hemolitik streptococcus), Staphylococcus aureus, Haemophilus influenza serta bakteri aerob yaitu Fusobacterium, Prevotella, Porphyromonas, dan Peptostreptococcus spp. yang menginfeksi tenggorokan ke salah satu ruangan areolar yang longgar di sekitar faring menyebabkan terjadinya abses, jika infeksi telah menembus kapsul tonsil tetapi tetap dalam batas otot konstriktor faring. Makalah ini melaporkan dan membahas tentang tatalaksana luka akibat pecahnya abses peritonsilar. Kasus berupa pasien pria berusia 36 tahun dengan keluhan luka pada langit-langit, pasien sulit menelan serta terdapat pembengkakan pada tonsil. Diagnosis dari kasus ini adalah luka karena pecahnya abses peritonsilar. Terapi diberikan untuk mengatasi luka akibat pecahnya peritonsilar abses berupa antibiotik amoksisilin dan obat kumur benzidamin $\mathrm{HCl}$
\end{abstract}

Key words: abses peritonsilar, infeksi daerah kepala leher, benzidamine $\mathrm{HCl}$

Koresponden: Astrid Palmasari, Fakultas Kedokteran Gigi Universitas Hang Tuah, Jl. Arief Rachman Hakim No.150, Surabaya, Indonesia. E-mail: pastrid81@yahoo.com

\section{PENDAHULUAN}

Abses peritonsilar adalah penyakit yang sering terjadi pada kepala dan leher, merupakan kelanjutan dari tonsilitis dan menyebar ke kelenjar getah bening di spatium parafaringeal. Abses peritonsilar merupakan kumpulan pus yang terlokalisasi pada jaringan peritonsilar yang terbentuk sebagai hasil dari tonsilitis yang supuratif. ${ }^{1}$

Penyakit ini dapat terjadi pada rentang usia 10-60 tahun, namun paling sering terjadi pada usia 20-40 tahun. Pada anak dengan usia yang lebih muda, abses peritonsilar dapat terjadi karena menurunnya imunitas. Perbandingan jumlah penderita pria dan wanita adalah sama. Tidak ada predileksi ras pada abses peritonsilar. Di Amerika serikat angka kejadiannya sebesar 30 kasus per 100.000 orang per tahun. ${ }^{2}$

Etiologi penyakit ini adalah gabungan dari bakteri aerobik dan anaerobik di daerah peritonsilar. Tempat yang bisa berpotensi terjadinya abses peritonsilar adalah di daerah pilar tonsil anterior, fossa piriformis inferior, dan palatum superior. Abses peritonsilar terbentuk oleh karena penyebaran bakteri anaerob, yaitu Streptococcus pyogenes (Group A Beta-Hemolitik streptococcus), Staphylococcus aureus, Haemophilus influenzae. Sedangkan organisme anaerob yang berperan adalah Fusobacterium, Prevotella, Porphyromonas, dan Peptostreptococcus spp.

Abses peritonsilar terbentuk oleh karena penyebaran mikroorganisme bakteri penginfeksi tenggorokan ke salah satu ruangan areolar yang longgar di sekitar faring menyebabkan pembentukan abses. Infeksi telah menembus kapsul tonsil tetapi masih dalam batas konstriktor faring. ${ }^{4}$

Gambaran klinis peritonsilar abses adalah nyeri telan, dapat hanya pada satu sisi, disfagia, 
perubahan suara, pusing, meriang, demam, sakit leher belakang, otalgia, rinolalia, regurgitasi, foetor ex ore, trismus, pembengkakan kelenjar mandibula. Pada daerah superior dan lateral fossa tonsilaris yang merupakan jaringan ikat longgar memungkinkan terjadinya infiltrasi supurasi ke ruang potensial peritonsil, sehingga tampak palatum mole membengkak. Abses peritosil juga dapat terbentuk di bagian inferior tetapi jarang. Apabila abses pecah, maka dapat terjadi aspirasi ke paru-paru. ${ }^{5}$

Artikel ini melaporkan pasien yang mengalami abses peritonsilar, yang melanjut sehingga terjadi ruptur pada palatum mole. Dibahas mengenai pengawasan dan evaluasi pemberian terapi memperkuat diagnosis abses peritonsilar.

\section{KASUS}

\section{Kunjungan I}

Pasien laki-laki berusia 36 tahun datang ke Poli Gigi dan Mulut RSUD Dr. Soetomo dengan keluhan sariawan pada langit-langit sebelah dalam kiri sejak 2 minggu yang lalu. Mula-mula sariawan timbul kecil yang semakin lama semakin besar, dan bertambah sakit, sehingga penderita kesulitan menelan dan terasa mengganjal. Selama ini pasien hanya dapat memakan makanan yang lunak saja. Sebelumnya penderita telah berobat ke RSUD Dr Soedomo Trenggalek, diberi obat Amoxycillin tetapi tidak membaik. Selanjutnya diberi obat Cefadroxil dan Dexamethason, tetapi juga tidak mengalami perbaikan sehingga dirujuk ke RSUD Dr. Soetomo. Dari anamnesis diketahui penderita tidak teratur meminum obat-obatnya.

Pada pemeriksaan ekstra oral didapatkan kelenjar submandibularis kiri teraba, lunak, dan nyeri. Pada pemeriksaan intra oral didapatkan ulser tunggal pada palatum kiri, ukuran $1,2 \mathrm{~cm}$, bentuk tidak beraturan, tepi kemerahan, dan di bagian tengahnya terdapat eksudat berwarna kekuningan (Gambar 1A). Pada tonsil sebelah kiri didapatkan adanya pembengkakan, dan warna kemerahan. Berdasarkan dari anamnesis dan pemeriksaan klinis, didiagnosis sementara sebagai Gonorrhoea stomatitis, infeksi kelenjar liur, mononukleosis oleh karena virus Eipstein barr.

\section{TATA LAKSANA KASUS}

Sebagai penanganan awal, pasien diberi terapi obat kumur benzydamine HCL. Selanjutnya pasien dirujuk ke Laboratorium Mikrobiologi untuk pemeriksaan kultur mikrobiologi untuk memastikan adanya bakteri Diplococcus Neisseria gonorrhoae

\section{Kunjungan II}

Dari hasil anamnesis diketahui bahwa setelah menggunakan obat kumur benzydamine HCL rasa sakit dan tidak nyaman waktu menelan sudah berkurang. Hasil pemeriksaan ekstra oral normal, sedangkan pada pemeriksaan intra oral ulserasi pada palatum mole kiri sudah tidak tampak kemerahan, eksudat tampak hanya tinggal sedikit (Gambar 1B). Pasien diberi Amoxycillin+asam clavulanat tablet $3 \times$ sehari, kalium diklofenak 50 mg 2 x sehari, obat kumur benzydamine $\mathrm{HCl}$ tetap dilanjutkan untuk kontrol selanjutnya.

\section{Kunjungan III}

Pada hari ke-8, pasien merasa sudah dapat menelan dengan lebih nyaman, tidak ada lagi keluhan rasa nyeri. Obat amoxycillin+asam clavulanat tidak dikonsumsi lagi karena pasien merasa gatal-gatal di badan setelah meminum obat tersebut, tetapi kalium diklofenak dan obat kumur benzydamine HCL tetap dilanjutkan. Hasil pemeriksaan laboratorium tidak terdapat Neisseria gonorrhoea, hanya terdapat bakteri Streptococcus viridans. Pasien didiagnosis sebagai abses peritonsiler.
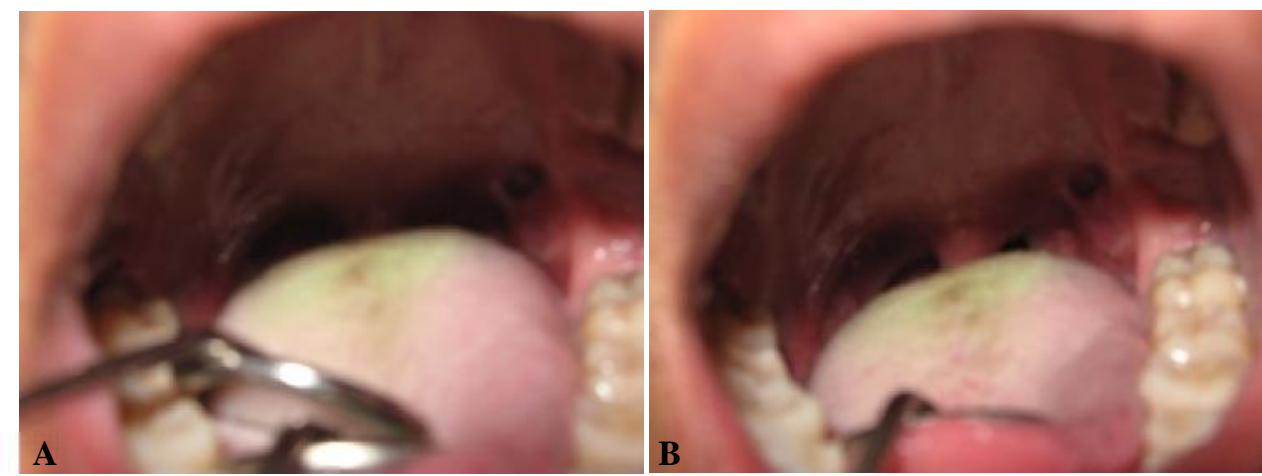

Gambar 1. Tampak intra oral pada kunjungan I, ulkus pada palatum kiri; B. Kunjungan ke II, ulkus sudah tidak terlalu kemerahan lagi 

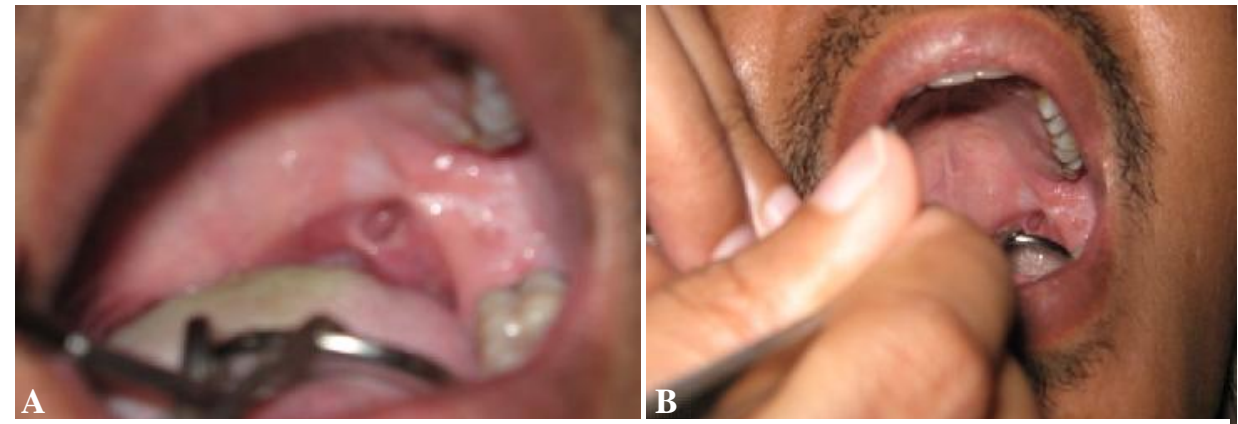

Gambar 2. A. Kunjungan ke III, ulkus mengecil; B. Kunjungan ke IV, ulkus sudah sembuh dan menimbulkan jaringan sikatriks

Hasil uji sensitivitas menunjukkan bahwa antibiotik yang sensitif ialah Ampicillin. Hasil pemeriksaan ekstra oral normal, sedang pada pemeriksaan intra oral eksudat pada palatum mole sudah tidak tampak, pembengkakan pada tonsil berkurang, tetapi masih tampak asimetris bila dibandingkan yang sebelah kanan (Gambar 2A). Untuk medikasi diberikan Ampicillin 500 mg 3 x sehari, multivitamin $2 \mathrm{x}$ sehari, dan obat kumur benzydamine HCL tetap dilanjutkan.

\section{Kunjungan IV}

Pada hari ke-32, pasien merasa sudah dapat menelan dengan normal, dan rasa nyeri sudah tidak ada sama sekali. Pasien dengan teratur menghabiskan obat Ampicillin tablet $500 \mathrm{mg}$, dan tidak terasa gatal-gatal. Pemeriksaan ekstra oral tampak normal. Pada pemeriksaan intra oral tampak ulser pada palatum sudah mengecil sebesar $1 \mathrm{~cm}$, dan terdapat jaringan sikatrik di sekitar ulkus. Sebelah kiri dan kanan tonsil telah tampak lebih simetris. Pasien juga diberi obat kumur klorheksidin dan multivitamin+mineral $2 \mathrm{x}$ sehari, lalu dirujuk ke Poli THT untuk mendapat perawatan pada defek di palatum mole.

\section{PEMBAHASAN}

Abses peritonsilar terjadi akibat komplikasi tonsilitis akut atau infeksi yang bersumber dari kelenjar mukus Weber di kutub atas tonsil. Kuman penyebabnya sama dengan penyebab tonsilitis akut, yaitu gabungan bakteri aerob dan anaerob. Biasanya terletak unilateral dan sering terjadi pada anak, dan dewasa muda. ${ }^{6}$

Pada umumnya lokasi gonococcal stomatitis adalah pada daerah posterior rongga mulut, antara lain sebagai gambaran neisseria kataralis. Gambaran lesi gonococcal stomatitis adalah lesi yang tidak spesifik karena mirip dengan ulkusulkus rongga mulut lainnya. Akan tetapi, pada lesi gonocccal somatitits didapatkan adanya pus di permukaan lesi. ${ }^{7}$ Hasil anamnesis mengenai pola hidup, serta latar belakang kehidupan penderita sebagai petani tidak menunjang kelainan tersebut. Untuk memastikan diagnosis, pasien dirujuk untuk pemeriksaan kultur mikrobiologi untuk melihat adanya Neisseria gonorrhoae.

Sementara menunggu hasil pemeriksaan laboratorium, diberikan obat kumur benzydamine HCL untuk meredakan nyeri. Hasil laboratorium menunjukkan tidak ditemukan N.gonorrhoae, hanya ditemukan S.viridans. Hal tersebut berarti lesi bukan merupakan suatu gonorrhoae stomatitis karena S.viridans adalah flora normal dalam rongga mulut. Oleh karena itu diagnosis ditegakkan sebagai abses peritonsiler. Untuk medikasinya, diberikan terapi antibiotik, pereda rasa nyeri, dan obat kumur klorheksidin.

\section{SIMPULAN}

Terapi yang diberikan untuk mengatasi luka akibat pecahnya abses peritonsilar berupa antibiotik, pereda nyeri, dan obat kumur benzydamine $\mathrm{HCl}$. Pada Kontrol satu bulan pasien menyatakan sudah merasa nyaman.

\section{DAFTAR PUSTAKA}

1. Bayley BJ. Tonsilitis, tonsilectomy and adenoidectomy. In: Head and neck surgeryotolaryngology. 2nd Ed. Philadelphia: Lippincott Raven Publisher; 2005. p. 1224-34.

2. Anurogo D. Tips praktis mengenali abses peritonsil. 2008. Available from: http://www.kabarindonesia. com/berita.php?pil=3\&dn=20080125161248. Accesed at 2008

3. Preston M. Peritonsillar Abscess (Quinsy). 2008. Available from: http://www.patient.co.uk./showdoc/ 4000961/.Accesed 2008

4. Mehta N. Pertonsillar abscess. 2007. Available from www.emedicine.com Accesed at June 2009.

5. Soepardi EA, Iskandar NH. Abses peritonsiler, Buku ajar ilmu kesehatan telinga, hidung, tenggorokan, Jakarta: FK UI, 2000 185-9

6. Steyer TE. Peritonsillar abscess: diagnosis and treatment 2002. Available from: http://www. aafp.org/afp/20020101/93.html. Accesed at 2007. 
